\title{
RABEP1/PDGFRB Fusion Gene
}

National Cancer Institute

\section{Source}

National Cancer Institute. RABEP1/PDGFRB Fusion Gene. NCI Thesaurus. Code C99591.

A fusion gene that results from a chromosomal translocation $\mathrm{t}(5 ; 17)(\mathrm{q} 33 ; \mathrm{p} 13)$ which fuses most of the RABEP1 gene with the 3' part of the PDGFRB gene. This gene fusion is associated with chronic myelomonocytic leukemia. 